\title{
Penyingkapan Diri Perempuan Penyintas Kekerasan Seksual
}

\author{
Rini Oktaviani, Suzy S. Azeharie \\ rini.octaviani15@gmail.com,suzya@fikom.untar.ac.id \\ Fakultas Ilmu Komunikasi Universitas Tarumanagara
}

\begin{abstract}
The high rate of sexual violence including rape and sexual harassment in Indonesia is a problem that has not been resolved. However, it cannot be concluded that cases of rape and sexual harassment are increasing, but more and more women survivors report cases they have experienced. Women dare to speak and not be influenced by the opinion of the majority who blame victims of sexual violence. One interesting phenomenon to be reviewed is the selfdisclosure of women survivors of rape and sexual harassment of consorts. This study aims to determine the self-disclosure by women survivors of rape and sexual harassment at the escort and the reasons for women survivors of rape and sexual harassment to disclose themselves to the companion. The theory used is the theory of interpersonal communication, self-disclosure, the spiral of silence and patriarchal culture. This study uses a descriptive qualitative approach with the phenomenological method. Data analyzed were obtained from interviews with four survivors of rape and survivors of sexual harassment. The results of this study are the disclosure of survivors of rape and survivors of sexual harassment to companions is important so that victims do not bear their own problems and can immediately recover. Survivors can find people who at least have experience in support and people who can be trusted to listen to self-disclosure. But different things were found in the companion who is the mother of survivors and sexual harassers. The survivor's mother ignored the incident of abuse experienced by the survivor and assumed that the incident had never happened because the perpetrator was a person who was of one flesh and blood with the survivor.
\end{abstract}

Keywords: rape, self disclosure, sexual harassment, survivors, spiral of Silence theory

\begin{abstract}
Abstrak
Tingginya angka kekerasan seksual termasuk perkosaan dan pelecehan seksual di Indonesia menjadi permasalahan yang sampai saat ini belum terselesaikan. Namun tidak dapat disimpulkan bahwa kasus perkosaan dan pelecehan seksual semakin bertambah melainkan semakin banyak perempuan penyintas yang melaporkan kasus yang mereka alami. Perempuan berani bersuara dan tidak terpengaruh dengan pendapat mayoritas yang menyalahkan korban kekerasan seksual. Salah satu fenomena yang menarik untuk diulas adalah penyingkapan diri perempuan penyintas perkosaan dan pelecehan seksual pada pendamping. Penelitian ini bertujuan untuk mengetahui penyingkapan diri yang dilakukan perempuan penyintas perkosaan dan pelecehan seksual pada pendamping dan alasan perempuan penyintas perkosaan dan pelecehan seksual melakukan penyingkapan diri pada pendamping. Teori yang digunakan adalah teori komunikasi interpersonal, penyingkapan diri, spiral keheningan dan budaya patriarki. Penelitian ini menggunakan pendekatan kualitatif deskriptif dengan metode fenomenologi. Data yang dianalisis diperoleh dari hasil wawancara dengan empat penyintas perkosaan dan penyintas pelecehan seksual. Hasil dari penelitian ini adalah penyingkapan diri penyintas perkosaan dan penyintas pelecehan seksual pada pendamping penting dilakukan agar korban tidak menanggung masalahnya sendiri dan dapat segera memulihkan diri. Penyintas bisa mencari orang yang setidaknya mempunyai pengalaman dalam mendukung dan orang yang bisa dipercaya untuk mendengarkan penyingkapan diri. Namun hal berbeda ditemui pada pendamping yang merupakan ibu dari penyintas dan pelaku pelecehan seksual. Ibu si penyintas mengabaikan peristiwa pelecehan yang dialami penyintas dan menganggap
\end{abstract}


bahwa peristiwa tersebut tidak pernah terjadi karena pelaku adalah orang yang satu darah daging dengan penyintas.

Kata Kunci: penyingkapan diri, perkosaan, pelecehan seksual, penyintas, teori spiral keheningan

\section{Pendahuluan}

Angka kekerasan seksual terhadap perempuan di Indonesia setiap tahunnya mengalami peningkatan. Keprihatinan terhadap korban kekerasan seksual semakin mengemuka karena banyaknya kasus kejahatan seksual yang tidak terselesaikan secara tuntas. Berbagai bentuk kekerasan seksual seperti pemerkosaan dan pelecehan seksual lebih banyak terjadi pada perempuan daripada laki-laki. Perkosaan dan pelecehan seksual yang dialami oleh perempuan kurang mendapatkan respon dari masyarakat. Salah satu penyebabnya adalah perkosaan dan pelecehan seksual dipahami sebagai persoalan personal dan domestik. Apabila seorang perempuan menjadi korban perkosaan dan pelecehan seksual maka dikaitkan dengan kepribadian dan perilaku korban yang dianggap menyebabkan tindakan kejahatan tersebut.

Menurut data Catatan Tahunan Komisi Nasional Anti Kekerasan terhadap Perempuan yang dirilis Maret 2019, jumlah kekerasan terhadap perempuan pada tahun 2018 mengalami peningkatan yaitu sebesar 406.178. Angka tersebut naik sekitar 14\% dibandingkan dengan Catatan Tahunan Komnas Perempuan 2018 yaitu sebesar 348.466 kasus. Sementara itu, data yang masuk dari lembaga mitra pengada layanan terdapat 13.568 kasus kekerasan terhadap perempuan dengan jumlah kasus kekerasan seksual di ranah personal sebanyak 2.988 kasus. Sedangkan kekerasan seksual di ranah publik mencapai 2.521 kasus. Adapun bentuk kekerasan seksual yang paling banyak dilaporkan adalah perkosaan dan pelecehan seksual (https://www.komnasperempuan.go.id/read-news-lembar-fakta-dan-poin-kuncicatatan-tahunan-komnas-perempuan-tahun-2019 diakses pada tanggal 6 Oktober 2019 pukul 2:21 WIB).

Kasus perkosaan dan pelecehan seksual yang dialami penyintas umumnya terjadi karena kuatnya budaya patriarki di masyarakat. Patriarki menurut Sylvia Walby adalah sebuah sistem struktur sosial dan praktik yang memposisikan laki-laki sebagai pihak yang mendominasi, menindas dan mengeksploitasi perempuan (Walby, 2014). Hal tersebut juga memperlihatkan bahwa saat ini telah terjadi pergeseran nilai-nilai sosial di dalam kehidupan masyarakat Indonesia sehingga masyarakat cenderung menganggap wajar perilaku perkosaan dan pelecehan seksual seksual terhadap perempuan dalam bentuk kecil.

Pendapat di atas senada dengan Elly Nur Hayati dalam Jurnal Perempuan yang menyatakan bahwa perkosaan dan pelecehan seksual yang dialami perempuan menjadi satu bagian yang tidak terlupakan dalam sistem kehidupan sosial masyarakat. Seringkali perempuan korban perkosaan dan pelecehan seksual dipojokkan dan disalahkan (Hayati, 2002). Perempuan korban perkosaan dan pelecehan seksual dianggap 'mengundang' aksi perkosaan dan pelecehan seksual dengan memakai baju seksi atau berjalan sendiri di malam hari.

Pemikiran tersebut semakin memperburuk kondisi saat ini. Stigma yang diberikan oleh orang lain menyebabkan korban merasa tertekan secara emosional. Rasa takut akan diisolasi dari masyarakat membuat perempuan korban perkosaan dan pelecehan seksual menutup rapat peristiwa buruk yang dialaminya. Banyak perempuan yang menjadi korban mengalami ancaman dan tekanan sehingga tidak 
berani melaporkan kejahatan yang dialaminya. Hal tersebut menjadi salah satu alasan korban membiarkan masalah perkosaan dan pelecehan seksual. Korban merasa kasusnya tidak perlu ditangani secara hukum. Jika korban menginginkan penanganan masalah yang dialaminya maka dianggap cukup diselesaikan secara pribadi oleh korban. Hal tersebut untuk menghindari penanganan secara publik maupun penyelesaian melalui jalur hukum sehingga pelaku perkosaan dan pelecehan seksual akan bebas berkeliaran. Tidak menutup kemungkinan makin banyak pelaku perkosaan dan pelecehan seksual lain melakukan tindakan kejahatan tersebut.

Akan tetapi, ada beberapa korban perkosaan dan pelecehan seksual yang tidak terpengaruh dengan pendapat mayoritas yang menyalahkan korban kekerasan seksual. Kelompok tersebut dinamai hard core. Adapun yang termasuk ke dalam kelompok hard core antara lain Komisi Nasional Anti Kekerasan terhadap Perempuan, aktivis, pendamping dan penyintas yang berani melaporkan kasusnya ke jalur hukum. Penyintas mewakili sekelompok individu yang berani mengungkapkan kasusnya dan tidak takut akan ancaman isolasi. Mereka adalah orang-orang yang sadar bahwa sikapnya menentang opini mayoritas dan berusaha memperjuangkan apa yang mereka yakini sampai suatu saat nanti opini publik ini akan berbalik (West dan Turner, 2014).

Perempuan penyintas perkosaan dan pelecehan seksual melakukan komunikasi pada pendamping. Dalam proses ini perempuan penyintas perkosaan dan pelecehan seksual dapat melakukan penyingkapan diri pada pendamping. Penyingkapan diri menurut Joseph A. DeVito merupakan komunikasi yang berisi informasi mengenai diri sendiri yang biasanya disembunyikan dari orang lain (DeVito, 2011). Penyingkapan diri dilakukan perempuan penyintas perkosaan dan pelecehan seksual dengan orang yang diyakini dapat dipercaya. Dengan penyingkapan diri maka penyintas perkosaan dan pelecehan seksual dapat memperoleh dukungan dalam menghadapi masa-masa sulit.

Banyak pertimbangan yang dilakukan seseorang sebelum dirinya memutuskan untuk membuka diri. Dukungan dan penerimaan dari keluarga sangat penting bagi kepercayaan diri orang tersebut meskipun terdapat pro dan kontra dari berbagai pihak (Ghiyats, 2017)

Berdasarkan latar belakang di atas, rumusan masalah dalam penelitian ini yaitu bagaimana penyingkapan diri perempuan penyintas perkosaan dan pelecehan seksual pada pendamping? Mengapa perempuan penyintas perkosaan dan pelecehan seksual melakukan penyingkapan diri pada pendamping?" Adapun tujuan dari penelitian adalah untuk mengetahui penyingkapan diri yang dilakukan perempuan penyintas perkosaan dan pelecehan seksual pada pendamping dan untuk mengetahui mengapa perempuan penyintas perkosaan dan pelecehan seksual melakukan penyingkapan diri pada pendamping.

\section{Metode Penelitian}

Metode dalam penelitian ini menggunakan deskriptif kualitatif dengan menggunakan pendekatan fenomenologi. Penelitian kualitatif adalah sebuah metode penelitian untuk mencari makna, pemahaman, pengertian mengenai suatu fenomena, kejadian maupun kehidupan manusia yang terlibat secara langsung maupun tidak langsung. Penelitian kualitatif mengumpulkan data melalui berbagai tahap dan makna yang disimpulkan selama proses berlangsung dari awal sampai akhir kegiatan (Yusuf, 2014). Metode deskriptif sebagai suatu metode dalam meneliti sekelompok manusia, objek, kondisi, sistem pemikiran ataupun peristiwa pada masa sekarang. Tujuannya 
adalah untuk membuat deskripsi dan gambaran fenomena yang diselidiki secara sistematis, faktual dan akurat (Nazir, 2011).

Penelitian ini dilakukan dengan melakukan wawancara semi-terstruktur yang termasuk dalam kategori wawancara mendalam. Penulis lebih bebas bertanya dibandingkan dengan wawancara terstruktur. Adapun tujuan dari wawancara ini agar menemukan permasalahan secara lebih terbuka karena informan akan diminta pendapat serta tanggapannya. Dalam melakukan wawancara semi-terstruktur, penulis perlu mendengarkan dengan teliti dan mencatat informasi yang disampaikan oleh informan (Sugiyono, 2011). Selain itu penulis juga melakukan observasi non partisipan pada perempuan penyintas perkosaan dan penyintas pelecehan seksual. Observasi non partisipan adalah observasi yang tidak melibatkan penulis secara langsung dalam suatu kelompok yang diteliti. Penulis hanya mengamati, mencatat, menganalisis dan membuat kesimpulan saat wawancara (Sugiyono, 2011).

Penelitian ini menggunakan metode fenomenologi karena dianggap membantu penulis menggambarkan fakta dan keadaan yang dialami oleh perempuan penyintas perkosaan dan pelecehan seksual yang melakukan penyingkapan diri pada pendamping. Penyintas perkosaan dan pelecehan seksual berani menyuarakan pendapatnya tentang perkosaan dan pelecehan seksual walau berbeda dari opini mayoritas tanpa rasa takut akan diisolasi oleh masyarakat. Mereka berusaha memperjuangkan keadilan sampai suatu saat nanti opini publik ini akan berbalik.

\section{Hasil Temuan dan Diskusi}

Berdasarkan wawancara dan observasi non partisipan yang telah penulis lakukan kepada penyintas perkosaan dan penyintas pelecehan seksual yang menjadi key informan dalam penelitian ini. Saat melakukan wawancara, perempuan penyintas perkosaan berinisial SR mengatakan bahwa penyingkapan diri dilakukan agar ia merasa tidak sendiri lagi. Ketika bekerja di Yayasan Jurnal Perempuan pada tahun 2008, SR banyak belajar tentang feminisme. Kemudian ia berpikir bahwa masih sedikit penyintas yang berani untuk melakukan penyingkapan diri. Banyak perempuan yang mengalami perkosaan dan merasa sendirian. Sejak saat itu ia mulai memberanikan diri untuk melakukan penyingkapan diri ke publik. Penyingkapan diri yang dilakukan SR juga mendorong perempuan penyintas yang pernah mengalami perkosaan dan pelecehan seksual berani melakukan penyingkapan diri mengenai masalah yang dialaminya. Menurut SR, penyingkapan diri akan membantu penyintas untuk memulihkan diri. SR mengatakan bahwa perkosaan yang terjadi tidak membuat dunianya berakhir. Meskipun hidupnya tidak pernah sama lagi. Tetapi bukan berarti seorang penyintas tidak bisa menjadi diri sendiri dan membentuk diri sesuai dengan keinginan penyintas.

Sejalan dengan pendapat di atas, Citra Maudy mengatakan bahwa Jakarta Post memberitakan kelanjutan kasus Agni (bukan nama sebenarnya) dalam kasus dugaan pelecehan seksual di kampus UGM. Dalam pemberitaan tersebut disebutkan bahwa Agni mengatakan bahwa tidak semua tuntutan bisa terpenuhi. Namun Agni sudah berjuang melakukan banyak hal. Selain itu, saat ini UGM sedang mengesahkan peraturan pencegahan kekerasan seksual. Pers kampus, Balairung Press juga ikut mengawal penulisan peraturan tersebut. Peraturan tersebut cukup progresif dan dianggap memihak perempuan. Menurut Citra, secara tuntutan Agni tidak menang, tapi ia menang secara perjuangan. 
Beberapa dari penyintas mendapatkan dukungan dari pendamping ketika melakukan penyingkapan diri. Citra Maudy mengatakan bahwa Agni juga mendapatkan dukungan dari teman-temannya. Agni merasa beruntung karena dikelilingi oleh teman-teman yang suportif. Rekan-rekan ini menyemangati Agni untuk terus berjuang mendapatkan keadilan. Mereka mendampingi Agni selama proses pengurusan kasus perkosaan ke pihak universitas. Bahkan teman-teman Agni juga menemani datang ke Rifka Annisa yang merupakan lembaga advokasi kekerasan seksual dan isu-isu tentang perempuan. Sementara itu, Citra Maudy juga memberikan dukungan kepada Agni. Citra selalu memberikan informasi mengenai perkembangan kasus Agni di universitas. Citra juga pernah menemani Agni ke kantor polisi untuk menangani kasus perkosaan yang dialami Agni. Mereka saling mendukung satu sama lain. Namun hal berbeda ditemukan ketika penyintas pelecehan seksual, SA melakukan penyingkapan diri kepada ibunya. Ia tidak mendapatkan dukungan dari ibunya. Ibunya hanya menangis dan tidak memberikan jalan keluar dari pelecehan seksual yang terjadi padanya. Bahkan setiap kali SA membahas mengenai pengalamannya, ibunya mengabaikan dan menganggap bahwa pelecehan seksual tersebut tidak pernah terjadi karena pelaku adalah kakak kandung SA.

Sebagai makhluk sosial, manusia tidak dapat untuk tidak berhubungan dengan manusia lain. Oleh karena itu, manusia harus mampu membina hubungan yang harmonis dengan sesamanya. Agar dapat diterima maka terlebih dahulu manusia harus mengungkapkan diri kepada orang lain (Azeharie, 2015:5). Akan tetapi, setelah melakukan penyingkapan diri mereka merasa adanya victim blaming dari orang-orang yang ada di sekitarnya.

Saat penulis melakukan wawancara dengan SR, ia menjelaskan bahwa ketika kasus perkosaan oleh mantan pacarnya dilaporkan ke kantor polisi ia mendapat perlakuan yang tidak baik. Ia diberikan pertanyaan-pertanyaan yang membuatnya merasa tidak nyaman. Bentuknya seperti diinterogasi oleh polisi. Pertanyaan tersebut antara lain, "sebelumnya pernah pacaran atau tidak, kalau pernah pacaran sudah berapa kali pacaran, sebelumnya pernah melakukan hubungan intim atau tidak?” Polisi juga menanyakan SR mengenai pakaian yang ia kenakan. Menurutnya, pertanyaanpertanyaan tersebut tidak perlu ditanyakan. Saat itu SR merasa bahwa ia mengulang mimpi buruk yang dialaminya. SR juga mendapatkan victim blaming dari sahabatsahabatnya. Ada beberapa sahabat yang menyalahkan dan menghakimi dirinya. Namun dari hal tersebut ia mengetahui bahwa tidak semua perempuan bisa memahami ketika ada perempuan lain yang mengalami kekerasan.

Hal senada juga dialami oleh Agni sebagai penyintas yang mengalami perkosaan. Agni merasakan victim blaming dari banyak pihak. Ketika Agni melaporkan kasus perkosaan yang dialaminya ke pihak UGM, kekhawatiran Agni terbukti dengan pernyataan salah satu pejabat Departemen Pengabdian kepada Masyarakat UGM. Pejabat tersebut menilai bahwa penyintas turut bersalah. Pejabat tersebut menganggap bahwa Agni bukan sebagai korban. Selain menilai Agni ikut berperan, ia juga menyayangkan Agni yang melibatkan pihak luar yaitu Rifka Annisa yang merupakan lembaga yang mengadvokasi kekerasan seksual dan isu-isu tentang perempuan. Menurutnya, kasus Agni lebih baik diselesaikan secara baik-baik dan kekeluargaan sehingga tidak mengakibatkan keributan. Ada juga pihak lain di departemen tersebut yang mengatakan bahwa Agni ikut berkontribusi pada terjadinya peristiwa. Pihak tersebut mengatakan bahwa Agni tidak bisa disebut sebagai korban. Ia juga menganalogikan Agni seperti 'kucing kalau diberi gereh (ikan asin, dalam Bahasa Jawa) pasti kan setidak-tidaknya akan dicium-cium atau dimakan'. Balairung 
Press menyatakan bahwa Adam Pamudji Rahardjo sebagai dosen pembimbing lapangan merasa malu dengan warga di lokasi Kuliah Kerja Nyata. Adam juga meminta Agni untuk bertobat atas perbuatannya.

Di laman Balairung Press UGM memuat komentar yang mayoritas menyalahkan Agni. Sementara itu, pembaca juga turut mempertanyakan alasan Balairung menceritakan kronologi perkosaan Agni secara detail. Ada juga yang berkomentar mengenai tindakan pelaku yang tidak bisa membaca situasi saat melakukan pemerkosaan kepada Agni. Kemudian ada juga yang menyalahkan tentang keputusan Agni untuk speak up ke publik. Menurut Citra, hal tersebut saling berhubungan dan menjadi bentuk victim blaming yang ditunjukkan kepada Agni.

Di sisi lain media berperan penting dalam pemberitaan mengenai perkosaan dan pelecehan seksual yang dialami oleh penyintas. Media dapat memberitakan mengenai penyintas secara positif maupun negatif. Media dapat menjadi sarana untuk mengkampanyekan anti kekerasan seksual sehingga semakin banyak orang yang lebih peduli mengenai isu-isu seperti ini. Namun media juga bisa melakukan hal sebaliknya. Tidak semua media memperhatikan kode etik jurnalistik dalam menuliskan suatu berita. Pemberitaan media bisa membentuk opini publik dan pengaruhnya akan sangat besar.

Sejumlah kasus perkosaan dan pelecehan seksual berlanjut hingga peradilan pidana. Hal ini karena korban memutuskan untuk menyelesaikan kasusnya secara hukum. Penyintas berinisial IS juga melaporkan pelecehan seksual kepada pihak kepolisian. Ia didampingi oleh kuasa hukum dari Lembaga Bantuan Hukum APIK. Ia menjalani proses laporan seperti melakukan berita acara perkara, gelar perkara dan rekonstruksi di tempat pelecehan seksual terjadi. Penyintas pelecehan seksual berinisial IS mengatakan bahwa ia menjalani proses hukum yang panjang dan melelahkan. Pelaku hanya menjalani hukuman selama tiga tahun penjara karena hasil banding pihaknya dengan jaksa penuntut hukum. Walaupun hukuman yang diperoleh pelaku tidak sebanding dengan hukuman yang berlaku, keinginan IS dan penyintas lainnya melanjutkan kasus pelecehan seksual ke ranah hukum telah membuktikan bahwa peristiwa tersebut terjadi dan bukan rekayasa serta pelaku mendapat hukuman.

Berikut ini penulis akan melakukan interpretasi data dengan mengaitkan data yang ditemukan dengan teori-teori yang digunakan dalam penelitian ini. Menurut Susanto (2010:7) komunikasi interpersonal adalah komunikasi perorangan yang sifatnya pribadi. Hal ini bisa dilakukan secara langsung melalui medium maupun tanpa melalui medium. Pada saat berkomunikasi, IS memberikan informasi mengenai kronologi pelecehan seksual secara detail kepada pendamping. Menurut IS, mau tidak mau pendamping harus mengetahuinya karena ia mempercayakan pendamping untuk membela dirinya (wawancara dengan IS di Giant Kreo, Jakarta Selatan pada tanggal 14 September 2019 pukul 16.00 WIB).

Sementara itu penyingkapan diri menurut Johnson adalah pengungkapan reaksi dan tanggapan seseorang terhadap situasi yang sedang dihadapinya serta memberikan informasi yang relevan tentang peristiwa masa lalu untuk pemahaman di masa kini (Harapan dan Ahmad, 2016:65). Saat penulis melakukan wawancara dengan SR, ia mengatakan bahwa penyingkapan diri yang dilakukan seorang penyintas tidak mudah. Penyingkapan diri dilakukan dengan melakukan pertimbangan secara cermat untuk meminimalisir resiko. Salah satu yang menjadi resikonya adalah tidak dipercaya oleh orang yang mendengar penyingkapan diri SR. Oleh karena itu, SR harus memahami alasan penyingkapan diri dengan baik sehingga ia dapat menentukan waktu, tempat dan cara melakukan penyingkapan diri secara tepat. Adapun alasan SR melakukan 
penyingkapan diri pada pendamping adalah kebutuhan akan dukungan dan bantuan dari psikolog untuk memulihkan diri serta kuasa hukum untuk menangani kasusnya secara hukum.

Teori Spiral Keheningan adalah teori yang menjelaskan seseorang yang yakin bahwa dirinya memiliki sudut pandang yang minoritas mengenai isu-isu publik dan terisolasi sehingga membatasi komunikasi mereka. Sedangkan orang yang memiliki sudut pandang mayoritas akan lebih terdorong untuk membuka suara. Teori ini mendefinisikan opini publik sebagai sikap atau perilaku yang harus diekspresikan seseorang di depan publik jika dirinya tidak ingin terisolasi. Elizabeth Noelle Neumann mengatakan bahwa opini publik dipengaruhi oleh siapa yang mengakui atau tidak mengakui pandangan seseorang (West dan Turner, 2014:122).

Dalam wawancara dengan Citra Maudy, ia berpendapat bahwa masih banyak orang yang meragukan pernyataan korban dan menyalahkan perbuatan korban. Hal tersebut mempengaruhi korban untuk tidak melakukan penyingkapan diri. Beberapa korban terpengaruh dan tidak melakukan penyingkapan diri ke publik maupun ke media. Bahkan ke orang terdekat sekalipun. Namun hal tersebut tidak terjadi pada Agni. Agni termasuk ke dalam kelompok hard core. Ia adalah seorang penyintas perkosaan yang mau bangkit dan berani angkat bicara mengenai perkosaan yang dialaminya. Walaupun hingga saat ini Agni belum sepenuhnya melakukan penyingkapan diri. Namun penyingkapan diri yang dilakukan Agni kepada Citra yang menuliskannya di Balairung Press telah membuktikan keberhasilan Agni memperjuangkan keadilan. Cerita Agni yang dituliskan secara detail di Balairung Press mengubah kondisi yang terjadi di lingkungannya. Agni menjadi lebih kuat meskipun mayoritas menyalahkannya. Lingkungan bisa menjadi faktor yang mendukung korban untuk sintas. Penyintas berhak mendapatkan keadilan.

Patriarki adalah sebuah sistem struktur sosial dan praktik-praktik yang memposisikan laki-laki sebagai pihak yang mendominasi, menindas dan mengeksploitasi kaum perempuan. Menurutnya, konsep patriarki masih sangat diperlukan untuk memahami ketidaksetaraan gender (Walby, 2014: 28). Menurut SR, kekerasan seksual berkaitan dengan budaya patriarki. Laki-laki yang diutamakan dan laki-laki adalah pemegang kuasa. Sementara perempuan adalah makhluk kedua. Dalam patriarki perempuan dijadikan sebagai objek seksual dan menjadi target kekerasan seksual. Kekerasan seksual yang dialami oleh perempuan disebabkan oleh tidak ada kesetaraan. SR mengatakan bahwa kesetaraan tidak menjadikan perempuan sama dengan laki-laki. Namun bukan berarti laki-laki berhak melakukan kekerasan seksual untuk menunjukkan relasi kuasa. Sehingga laki-laki dianggap patut untuk memerkosa perempuan.

\section{Simpulan}

Penyingkapan diri penyintas perkosaan dan penyintas pelecehan seksual pada pendamping relatif baik. Penyintas perkosaan dan penyintas pelecehan seksual ingin mendapatkan rasa saling percaya, pengertian dan kenyamanan sehingga mereka merasa memiliki ruang aman untuk melakukan penyingkapan diri. Namun hal berbeda ditemui pada pendamping yang merupakan ibu dari penyintas dan pelaku pelecehan seksual. Ibu si penyintas mengabaikan peristiwa pelecehan yang dialami penyintas dan menganggap bahwa peristiwa tersebut tidak pernah terjadi karena pelaku adalah orang yang satu darah daging dengan penyintas pelecehan seksual. 


\section{Ucapan Terimakasih}

Penulis mengucapkan terima kasih kepada orang tua penulis, kakak dan adik perempuan penulis, sahabat penulis, narasumber dan key informan yang telah meluangkan waktunya serta pihak-pihak lain yang telah memberikan dukungan, doa, nasihat dan semangat yang tiada hentinya sehingga dapat menyelesaikan penelitian ini dengan tepat waktu.

\section{Daftar Pustaka}

Azeharie, Suzy S. \& Sari, Wulan. P. (2015). Penyingkapan Diri Ibas Yudhoyono Dalam Instagram Dan Reaksi Yudhoyono Terhadap Postingan Instagram Ibas. September 19, 2019. Jurnal Komunikasi, Vol. 7, No. 1. Terasip di: https://journal.untar.ac.id/index.php/komunikasi/article/view/11

Devito, Joseph A. (2011). Komunikasi Antarmanusia. Pamulang-Tangerang Selatan: Karisma Publishing Group

Ghiyats, Fatinah \& Azeharie, Suzy S. (2017). Studi Proses Pengungkapan Jati Diri Transeksual. Desember 23, 2019. Jurnal Koneksi, Vol.1, No.2. https://journal.untar.ac.id/index.php/koneksi/article/view/2003

Jurnal Perempuan. (2002). Jurnal Perempuan 26: Hentikan Kekerasan Terhadap Perempuan. Jakarta: Yayasan Jurnal Perempuan.

Komnas Perempuan. (2019). Lembar Fakta dan Poin Kunci Catatan Tahunan Komnas Perempuan Tahun 2019. September 20, 2019. https://www.komnasperempuan.go.id/read-news-lembar-fakta-dan-poinkunci-catatan-tahunan-komnas-perempuan-tahun-2019

Nazir, Moh. (2011). Metode Penelitian. Bogor: Ghalia Indonesia.

Sugiyono. (2011). Metode Penelitian Pendidikan: Pendekatan Kuantitatif, Kualitatif, dan $R \& D$. Bandung: Alfabeta.

Walby, Sylvia. (2014). Teorisasi Patriarki. (Mustika K. Prasela, Penerjemah.). Yogyakarta: Jalasutra.

West, Richard dan Lynn H. Turner (2014). Pengantar Teori Komunikasi: Analisis dan Aplikasi. Edisi 3. Jakarta: Salemba Humanika.

Yusuf, Muri. (2014). Metode Penelitian: Kuantitatif, Kualitatif dan Penelitian Gabungan. Jakarta: Prenada media Group. 